\title{
Missio Dei - the contemporary missionary paradigm and its reception in the Eastern Orthodox missionary theology
}

\author{
Cristian SoneA*
}

\begin{abstract}
The purpose of this paper is to analyse the reception of the missio Dei paradigm in the Eastern Orthodox theology of mission. We will start with a short presentation of the genesis of the concept, and we will continue with its reception in the Protestant and Roman Catholic theology, as well as in the Eastern Orthodox thinking. The paper attempts to demonstrate that the contemporary way to understand the missionary theology and practice is in accordance with the Orthodox traditional missionary theology. At the same time, the article emphasizes the fact that the reception of missio Dei is connected with the view that different ecclesiastical bodies have about church itself. The conclusion includes some practical remarks about ways of applying the concept in the contemporary ecumenical missiology and in the field of spiritual missiology.
\end{abstract}

Keywords: missio Dei, ecumenical missiology, Eastern Orthodox missiology, indigenization of the gospel, spiritual missiology, mission from the margins, theosis.

\section{Introduction}

An authentic Christian theology will always have the mission to integrate the godly Revelation and the human experience. This is why the missionary theology applies the content of the faith to the concrete realities of the time. From this perspective, the missionary theology is characterized by an innovative dynamic: it discovers new meanings of the revealed truth, unchanged and unique, in an attempt to communicate the content of the Revelation to the contemporary human being. "This implies that this type of theology should be responsible for the faithful living at a certain time in history, meaning that it has to be a present day theology, making the content of the Revelation accessible to the people from that period, and that it has to be open to the eschatological future, having the task to direct the faithful to their true accomplishment in that future." ${ }^{1}$

\footnotetext{
* Cristian Sonea, Fr. Lecturer PhD. teaching Orthodox Missiology in the Faculty of Orthodox Theology, "Babeș-Bolyai” University, Cluj-Napoca, Address: Str. Albert Einstein, no. 10, ap. 1, Cluj-Napoca, Romania; e-mail: cristi_sonea@yahoo.com, cristisonea@gmail.com.

1 Constantine Skouteris, Perspective Ortodoxe, trans. by Ioan Marian Croitoru, Cluj, Presa Universitară Clujană 2008, p. 32.
} 
In various historical times, the Christian mission was understood in different ways. It has sometimes been interpreted in soteriological terms, as the people's work of salvation from the eternal fire ${ }^{2}$. It has also been understood in cultural terms, as an integration of the people from the East and South into the blessed and privileged world of the Christian West ${ }^{3}$. It has been often understood in ecclesial categories: as an expansion of the Church (or of a Christian denomination) into new missionary spaces ${ }^{4}$. In many cases, it was seen as a salvation of history, meaning the process through which the world - in an evolutional way or through a cataclysm - will be transformed in the Kingdom of God 5 . In all these different circumstances, the intrinsic relation among Christology, soteriology and the doctrine of the Holy Trinity, which was very important during early Christianity, became less obvious. After World War I, the missiologists began to look for the results of the new researches in the field of biblical and systematic theology, thus returning to the revealed truth and trying to recover the genuine Christian faith and lifestyle.

Therefore, the aim of this paper is to briefly present the understanding of the missio Dei concept and its reception and development in the Orthodox theology.

\section{Missio Dei, the contemporary missionary paradigm}

In a text read at the Brandenburg Missionary Conference in 1932, the protestant theologian Karl Barth became one of the first theologians who defined mission as a work of God Himself ${ }^{6}$. In Die Mission als theologisches Problem (1933), Karl Hartenstein affirms the same principle ${ }^{7}$, and some

2 David J. Bosch, Transforming mission: paradigm shifts in theology of mission, Maryknoll, New-York, Orbis Books 1991, p. 215-220.

3 Ibidem, p. 262-341.

4 See the different missionary models of teaching the Gospel in new missionary spaces is the following sources: S. Devasagayam Ponraj, An introduction to missionary anthropology: the principles and practices of communication of the gospel in cross-cultural contexts of India, Ayanavaram, Chennai, Mission Educational Books 1993; Johannes Verkuyl, Contemporary Missiology: An Introduction, Grand Rapids, W. B. Eerdmans Pub. Co 1978, p. 181-182; Francis Anekwe Oborji, Concepts of mission: the evolution of contemporary missiology, Maryknoll, New-York, Orbis Books 2006, p. 82-97; Lesslie Newbigin, The open secret: an introduction to the theology of mission, Grand Rapids, Wm. B. Eerdmans Publishing 1995, p. 66-91; Ecumenical Missiology: Contemporary Trends, Issues, and Themes, Bangalore, United Theological College 2002, p. 29-49; D. J. Bosch, Transforming mission, p. 181-348.

5 D. J. Bosch, Transforming mission, p. 181-190.

6 Karl Barth, „Die Theologie und Die Mission in der Gegenwart”, in: Zwischen den Zeiten 10, (3/1932), p. 189-215; D. J. Bosch, Transforming Mission, p. 11-17.

7 Karl Hartenstein, Die Mission als theologisches Problem: Beitrage zum grundsatzlichen Verstandnis der Mission, Berlin, Furche Verlag 1933. 
years later, at the Tambaram meeting of IMC (1938), the declaration of the German delegates represented a new stage in understanding mission as a work of God: „The delegates confessed that only 'through a creative act of God His Kingdom will be consummated in the final establishment of a new Heaven and a New Earth', and 'We are convinced that only this eschatological attitude can prevent the Church from becoming secularised'”. ${ }^{8}$

The influence of Karl Barth on the missionary theology has been crucial $^{9}$ and this was very obvious at the Willingen meeting of IMC 1952, where the content of the missio Dei doctrine was clearly presented for the first time (even though the terminology used was somewhat different ${ }^{10}$ ). From then on, the missionary theology has faced a radical change of paradigm, involving the transfer of the emphasis from an interpretation of the mission inside the autonomous anthropology, to its understanding as a work of God - the Holy Trinity ${ }^{11}$. "The Barthian conception [...] places the basis of the Christian mission on the doctrine of the Holy Trinity and not on ecclesiology or soteriology"12. At the same time, the understanding of mission as an action of a Christian denomination, whose aim is to plant new ecclesiological communities (plantatio ecclesiae) was re-evaluated. At Willingen, the Christian mission was said to arise from God himself and was placed in the context of the Trinitarian doctrine as well, not only in that of the ecclesiology ${ }^{13}$. The missio Dei doctrine ${ }^{14}$, understood as the sending of the Son and of the Holy Spirit, was extended to the idea that the Father, the Son and the Holy Spirit sent the Church into the world. Missio Dei became a mission accepted by the Protestant ${ }^{15}$ and Catholic Theologies as well as by the Orthodox Churches, for they all came to better understand it and consequently embrace it.

8 D. J. Bosch, Transforming mission, note 4, p. 390.

9 John G. Flett, The Witness of God: The Trinity, Missio Dei, Karl Barth, and the Nature of Christian Community, Grand Rapids - Cambridge, Wm. B. Eerdmans Publishing, 2010, p. 12.

10 Tormod Engelsviken, „Missio Dei: The Understanding and Misunderstanding of a Theological concept in European Churches and Missiology", in: IRM, vol. XCII, no. 367, p. 483; D. J. Bosch, Transforming mission, p. 390.

11 Timothy C. Tennent, Invitation to World Missions: A Trinitarian Missiology for the Twentyfirst Century, Grand Rapids, Kregel Academic 2010, p. 105-158.

12 Gheorghe Petraru, Misiologie ortodoxă. I. Revelaţia lui Dumnezeu şi misiunea Bisericii, Iași, Ed. Performantica 2000, p. 200.

13 Nicholas Lossky et al. (eds.), Dictionary of the Ecumenical Movement, Geneva, WCC Publications 2002, p. 780-781.

14 See more about the origin and the content of the missio Dei concept in: T. Engelsviken, „Missio Dei”, p. 482-486; D. J. Bosch, Transforming mission, p. 389-393.

15 Understanding, misunderstanding and the evolution of the missio Dei doctrine in the Western Eurpoean Churches is magistrally exposed by T. Engelsviken, „Missio Dei”, p. 481- 
As mentioned before, after Willingen, the understanding of missionary practice and theology as missio Dei has been adopted in all churches, especially in those engaged in ecumenical dialogs. According to David Bosch, the missio Dei paradigm was first embraced by the conciliar Protestantism, but also by other ecclesial bodies, including the Eastern Orthodox Churches, many evangelicals and the Catholic Church, as we can see from some of the documents of the Second Vatican Council ${ }^{16}$.

Missio Dei brings important consequences for the missio ecclesiae (the missionary activities of the church). As Stephen Neill puts it, referring to the post-Willingen theology of mission, "the age of missions is at an end; the age of mission has begun" " That means that the main purpose of the missio ecclesiae cannot be the planting of churches but to be service to the missio Dei, "representing God in and over against the world, pointing to God, holding up the God-child before the eyes of the world in a ceaseless celebration of the Feast of the Epiphany"18.

After Willingen, the missio Dei concept has had a different application in the ecclesial and the theological fields of the ecclesial bodies that embraced it. For instance, in Lutheran missiology the document of the Lutheran World Federation published in 1988 Together in God's Mission, missio $D e i$, as "God's own mission is larger than the mission of the church" ${ }^{19}$. In this case, the mission seems to be independent from the church and strictly understood as God's own activity. The Christological dimension of the mission of God is insufficiently stressed, leaving the impression that even the Christian character of mission is unimportant. The same Lutheran World Federation published in 2004 a new document about mission in which the relation between church and mission is re-evaluated. According to it, "mission is of the very being of the church. To be in mission is not optional for the church. Mission is constitutive of its being as the "one, holy, catholic, and apostolic" church (Nicene Creed)." ${ }^{20}$ Understanding missionary work

497; see also Dictionary of the Ecumenical Movement, p. 780-781; D. J. Bosch, Witness to the World. The Christian Mission in Theological Perspective, Eugene, Wipf and Stock Publisher 2006, p. 239-248; L. Newbigin, The Open Secret, p. 19-29.

16 D. J. Bosch, Transforming Mission, p. 390-91.

17 Stephen Neill, A History of Christian Missions, Harmondsworth, Penguin 1966, p. 527.

18 D. J. Bosch, Transforming Mission, p. 391.

19 Lutheran World Federation (ed.), Together in God's Mission: An LWF Contribution to the Understanding of Mission, 1988, p. 8.

20 Lutheran World Federation. Department for Mission and Development (ed.), Mission in Context: Transformation, Reconciliation, Empowerment. An LWF Contribution to the Understanding and Practice of Mission, Geneva, 2004, p. 28. 
in different contexts as a work of the local churches brings, in our opinion, a more appropriate view of God's work in history. „Since mission must be contextual for the faith to be rooted in people's real life experience, every church assumes primary responsibility for mission in its immediate locality and region." ${ }^{21}$ Even so, the LWF document distances itself from a narrow ecclesiastical view of mission testifying that "because of the apostolicity and catholicity of the church, proximity does not mean exclusive ownership of the practice of mission. Mission remains God's mission;"22. In the frame of missio Dei LWF sees the missionary responsibility as an ecclesiastical partnership, the missio Dei paradigm receiving in this case an ecumenical dimension. See below:

...individual Christians or families from different parts of the world may receive a call, from God through a sister church, to share mission responsibility with another church in a different geographical location or sociocultural situation. From this perspective, the role of and training for specialized ministries for international partnership in mission are very important. ${ }^{23}$

In the Roman Catholic theology of missio, according to D. Bosch, the understanding of mission is illustrated pneumatologically rather than christologically.

The history of the world is not only a history of evil but also of love, a history in which the reign of God is being advanced through the work of the Spirit. Thus, in its missionary activity, the church encounters a humanity and a world in which God's salvation has already been operative secretly, through the Spirit. This may, by the grace of God, issue in a more humane world which, however, may never be seen as a purely human product - the real author of this humanized history is the Holy Spirit. ${ }^{24}$

This is said taking into consideration the Vatican II's document "Pastoral Constitution on the Church in the Modern World" Gaudium et Spes. Indeed, the Second Vatican Council points out an essential departure from a "Roman Catholic ecclesiology that had primarily concerned itself with the external and institutional aspects of the church" 25 . According to

\footnotetext{
21 Ibidem, p. 45.

22 Ibidem.

23 Ibidem.

24 D. J. Bosch, Transforming Mission, p. 391.

25 Stephen B. Bevans, Roger P. Schroeder, Constants in Context: A Theology of Mission for Today, Maryknoll, New-York, Orbis Books 2004, p. 286.
} 
Stephen B. Bevans and Roger P. Schroeder Ad Gentes presents a definition of mission that involves regarding the church as „missionary by its very nature, because it itself is the result of the overflowing love of God, expressed in the mission of the Son and the mission of the Holy Spirit ( $A G$ 2)". Mission, consequently, is seen basically as

rooted in the continual self-giving and self-revelation of God within the history of creation; Trinitarian processions are understood not only as movements within the mystery of God, as such, but as God moving in saving love within the world. The church is then understood as the people that God has chosen not only to participate in the saving life of the divine community [...] but also to be agent and cooperator in God's outreach to the whole of creation. ${ }^{26}$

In particular, the Catholic Church - following its own way of understanding the ecclesiological existence - states that the Church is missionary in its very nature. The official position of the Church of Rome regarding mission was presented at the Second Vatican Council (1962-1965) in the „Decree Ad Gentes on the Missionary Activity of the Church”: „The Church is missionary by its nature, given that the spring of its missionary activity is the mission of the Son and of the Holy Spirit, as God the Father decided." The mission is "no more, nor less than a manifestation of God's plan, the epiphany and its realization across the world and throughout history." ${ }^{27}$ ( $A G$ I: 1, 9) According to Stephen B. Bevans and Roger P. Schroeder, Ad Gentes provided an important theological depth to the understanding of mission because the church received a missiological role since she was "graciously caught up in the missio Dei, the very mission of God in creation, redemption and continual sanctification". ${ }^{28}$

In short, there are two sides to this new emphasis on the theology of mission which arose from Willingen. God's mission benefits the world, therefore the Church should find its way to be a part of this redemption, for God's mission is defined "in terms of the Triune character and work of God". ${ }^{29}$ The

\section{St. B. Bevans, R. P. Schroeder, Constants in Context, p. 386-87.}

27 „The pilgrim Church is missionary by her very nature, since it is from the mission of the Son and the mission of the Holy Spirit that she draws her origin, in accordance with the decree of God the Father”; „Missionary activity is nothing else and nothing less than an epiphany, or a manifesting of God's decree, and its fulfillment in the world and in world history, in the course of which God, by means of mission, manifestly works out the history of salvation.", http://www.vatican.va/archive/hist_councils/ii_vatican_council/documents/ vat-ii_decree_19651207_ad-gentes_en.html accessed at 18 accessed at 18.04.2016.

28 St. B. Bevans, R. P. Schroeder, Constants in Context, p. 288.

29 Michael W. Goheen, "As the Father Has Sent Me, I Am Sending You”: J. E. Lesslie Newbigin's Missionary Ecclesiology, Utrecht, Proefschrift ter verkrijging van de graad van doctor aan de 
Trinitarian emphasis was of great importance, however there were differences when it came to the way churches accepted the missio Dei doctrine. As a result, a new perspective of missionary theology was observable and each Christian denomination proved to have a specific and unique understanding of ecclesiology. Willingen proposed an interpretation that led to defining the Trinitarian core of the mission from two different perspectives, on one hand as Christocentric Trinitarian, and on the other hand as cosmocentric Trinitarian. In this sense, the former aims to continue and develop the Christocentric tradition, which supported "the centrality and indispensability of the church in God's mission", while the latter sidelined the role of the church and served the purpose of "recognizing the providential work of the Father through the Spirit in culture and world history apart from Christ and the church." 30

The above mentioned signalled the need for a new interpretation of missio Dei. Paul Knitter, a well-known theologian preoccupied with the interreligious dialogue, proposed an interpretation of mission in a dialogical key and addressed the relational and dialogical nature of God. In his work, he expresses his belief that a coalescent relationship between God and His creation is fundamental for a real manifestation of free will. In this respect, mission is understood as dialogus Dei, and is seen as God's missio ad extra where "in the self-communicating mission of God, the Divine not only speaks, but listens, waits, values, challenges, and [...] learns from the response of creation". ${ }^{31}$

The practical consequences of missio Dei as a contemporary missionary paradigm can be found in the ecumenical missiology and in the present missionary practice in the Churches. For instance, the new missionary declaration of the Commission on World Mission and Evangelism (CWME), presented on the $10^{\text {th }}$ Assembly of the World Council of Churches (WCC) from Busan, Republic of Korea, in 2013, entitled Together towards Life $e^{32}$ proposes new understanding of the missionary model, consecrated under the phrase missio Dei. Mission as a work of God and our participation to His work, understood as a mission of the faithful into the Church, can be understood as a "mission from the margins". Therefore, mission from the margins means liberation from the Western model to make mission. In the

Universiteit Utrecht, 2000, p. 117, http://dspace.library.uu.nl/bitstream/handle/1874/597/ full.pdf?sequence $=1$, accessed at 17. 01. 2017.

30 Ibidem, p. 117-118, http://dspace.library.uu.nl/bitstream/handle/1874/597/full. pdf?sequence $=1$, accessed at 17. 01. 2017.

31 Paul F. Knitter, Jesus and the Other Names: Christian Mission and Global Responsibility, Maryknoll, New-York, Orbis Books 1996, p. 145.

32 See: Jooseop Keum (ed.), Together towards Life: Mission and Evangelism in Changing Landscape. New Affirmation on Mission and Evangelism (TTL), Commission on World Mission and Evangelism (CWME), WCC, 2013. 
Global South missiological thinking, the classical missionary model promoted by "the great missionary sending” (Matthew 28, 19-20) is understood as an imperialistic one. It is very Euro-centric, to the point that it does not include in the missions those who are the „object” of the missionary work. In this typology, according to the same missiological theology ${ }^{33}$, there is no reciprocity. That is why, in their view, the "Cornelius" model of "conversion before conversion" is much more appropriate for the contemporary context, and the model of the invitation to participate in missio Dei is more adequate for the unchristian world. The historical experiences of the Western missions in the countries from the Global South lead to the situation that we have today when many people from that part of the world consider Christianity to be a Western religion, European, alien to their culture and civilization. What missionary strategies must the Church use in such a circumstance? The model of the forced conversions is obsolete, and the receiving of a ,salvation message" from the colonizers has become, in time, un-believable. That is why the new understanding of the mission might be a successful one if it responds to the manner of thinking and living in the southern hemisphere. Invited to participate in the mission of God, Christians from the Global South have to discover the manner in which God was present and worked in their world, even before the proper missionary work. Mission as participation in the missionary work of God requires that the missionary who engages in the mission meets the work of God, Who has already worked in the new missionary context before him.

\section{The perception of the missio Dei paradigm in the Eastern Orthodox theology}

As for the Eastern Orthodox Church, missio Dei is in accordance with its own traditional view on mission, since the mission is not seen as an action performed exclusively by the Church, defined as an instrument of mission, but as the very providential intervention of God into history.

The classical understanding of the missionary work involved the notion of missionary spaces, of territory, of the visible extension of the Church into new communities of „unfaithful” people, while in the Eastern Orthodox Churches, "the mission is identified with the tradition” ${ }^{34}$, with the continuity of the Church over the centuries, with the conveyance of the faith

\footnotetext{
33 R. Roderick Hewitt, Chammah J Kaunda, „Together towards Life: Reconceptualising Missio - Formation in Changing Landscape of World Christianity", in: Pharos Journal of Theology, 96 (2015), p. 4-5.

34 Ion Bria (ed.), „Introduction” to Martyria / Mission: The Witness of the Orthodox Churches Today, Geneva, World Council of Churches 1980, p. 4.
} 
in time, from one generation to another. The objection of the Eastern Orthodox missionary theology to the Western understanding of the concept of mission consists of the fact that the latter has traditionally aimed at conquering new territories geographically, passing on not just the Gospel but a foreign culture as well. The Orthodox Churches, on the other hand, have tried to preserve the true faith in a living continuity along centuries and thus are tempted to focus on those who leave the Church rather than those who are not yet part of it. ${ }^{35}$

The outline of mission for the Eastern Orthodox Church was different. During the great Western missionary expeditions, most of the Orthodox world was under Ottoman domination, and the only Church that benefited from missionary freedom was the Russian Orthodox Church. The missionary spaces were delimited by the savages of Perm, a population that dwelled on the western side of the Urals, the Laplanders and the inhabitants of China, Siberia and by the dwellers of the Altai Mountains in Central Asia and in Alaska. The missionary model in such cases was slightly different. Nevertheless, the history of Russian missions witnessed some reprehensible moments as well. Some of the missionaries did not learn the language of the people they wanted to preach to, others were satisfied with using the secularist power to "convert" the "unfaithful", and internal disputes overwhelmed the Russian Church and hindered the missionary activity. We can mention in this respect the 1666 internal schism of the "possessors" and the "non-possessors", or the reforms of Peter the Great (1682-1725) which affected the mission of the Church. At the same time, monasticism was placed under strict imperialist control, which weakened its missionary force. In this context, Orthodoxy was not entirely unfamiliar with arguable missionary practices, which were usually associated with the Western world.

The missionary paradigm as stated in Willingen changes considerably the Western way of understanding and making mission. Since the mission is the work of God which continues throughout history, it is no longer seen as a work performed exclusively by a Church perceived as a missionary organisation.

Though the Orthodox Churches welcomed the changes brought by missio Dei, certain western interpretations of the mission, especially Protestant, are not in accordance with the Orthodox understanding of the concept. In the Protestant theology, the true Church is unseen and the visible church is represented by the society of the faithful sharing the same faith. Therefore, according to their understanding of mission, they support the idea that missio Dei can be achieved outside the boundaries of the Church as well. Given

35 Ibidem. 
that the supreme spring of mission is God, His work can sometimes happen outside the missionary institution. ${ }^{36}$ However, for the Orthodox theology, the mission can only happen within the Church, keeping in mind the fact that the understanding of the Church in general and its relationship with mission in particular is different, as we will clarify below.

\section{Understanding mission in the frame of missio Dei in the Orthodox Theology}

The ones that believe in the intimate communion with God are risen by salvation and theosis (deification), both manifested as extensions of the affectionate relationships between the divine and the conscious creatures. The Trinitarian God has a mission (missio Dei) essentially revealed in the work of salvation, whereas Trinity becomes the foundation of salvation. The Trinitarian God, makes possible for one of the three hypostases - namely for the One that is a Son in relation with the Other and who can stay in this affectionate relationship as Son and Man - to be made flesh, unanimously placing all of His brothers in relationship with the heavenly Father, His Father becoming this way Parent to all people. ${ }^{37}$ The revelation of Trinity as a result of the incarnation of the Son and his work on earth, as well as the descent of the Holy Spirit on the day of Pentecost are nothing but our attraction towards grace, or the Holy Spirit in the filial relationship of the Son with the Father. The revelation acts of the Trinity are acts of salvation and deification and raise us in communion with The Persons of the Holy Trinity. ${ }^{38}$

The involvement of Trinitarian theology in understanding the mission of the Church is very important. From this perspective, the mission of the Church starts with and is deeply rooted in the communion of the Holy Trinity, as seen in the love of the Father for the Son within the Holy Spirit, and towards mankind. ${ }^{39}$ For this reason, the mission of the Church does not serve as a main purpose, spreading and conveying intellectual beliefs and moral commandments, but transmits life as a communion in God, or attracts people to the communion with the Holy Trinity. In this way, "to be sent" in mission means "being part of" the sending of the Son (John 20, 2123) and of the Holy Spirit (John 14,26) which reveal God's life of communion $^{40}$ to have them become active participants in it, or to the Kingdom of

\footnotetext{
36 See T. Engelsviken, „Missio Dei”, p. 481-497.

37 Dumitru Stăniloae, Teologia Dogmatică Ortodoxă, Vol. I, Bucureşti, Ed. IBMBOR 1978, p. 285-286.

38 Ibidem, p. 286-287.

39 I. Bria, Curs de teologie şi practică misionară ortodoxă, Geneva, Bossey Library, 1982, p. 3.

40 I. Bria (ed.), Go Forth in Peace, Geneva, WCC 1986, p. 3.
} 
God, for the Kingdom of God is life in communion with the Holy Trinity, shared with mankind through Christ in the Holy Spirit.

God came into this world through Jesus Christ as a means of being the closest to us, therefore we can no longer postpone the preparation for the encounter with God until the end of our lives and of the entire mankind. Jesus himself is Who is expected in the future encounter with God. The teachings, the Person and the work of Christ is unified, therefore the Kingdom of God is around and unto us (Luke 17, 21). In the Person of Jesus Christ is the Kingdom of God in union and in the complete communion of God with man in Him. Jesus Christ becomes Teacher and Prophet because of His Own Person, revealing to the world, with the authority $\mathrm{He}$ has as God, the absolute truth about God, man, creation, about the salvation and completion of man in communion with God, confirming them all in His entire existence.

The person, the teachings and the activity of Jesus require immediate decision, with immediate consequences. Although Jesus emphasized the decisive character of His person and of His work, as well as of His immediate decision, he did not say that the end of the world had begun or was imminent. Therefore, in the teachings of Jesus Christ, the future is not without importance. On the contrary, His presence gives full meaning to the future, for the final aim of history, the Kingdom of God, is fulfilled in the rising and resurrection of Christ. The sacrifice and the resurrection of Christ generated something new and radical in the history of humanity changing the ontological condition of our existence. The life of God enters the life of mankind through the Risen Jesus Christ, changing life from its old state into a new state and preparing it for a future state. Starting with the resurrection of Christ, life and the history of mankind is oriented towards the Kingdom of God, which in an anticipatory form, is already among us here and now, as a kingdom of the Spirit. ${ }^{41}$ The life of God enters the life of humanity in the Risen Christ, changing her old state into a new state and preparing a future state. With the Rising of Christ, the life of mankind is oriented towards the Kingdom, which in an anticipatory form, is already among us here and now, as a kingdom of the Spirit ${ }^{42}$ and this happens in the Church.

From the point of view of the Eastern Orthodox theology, perceiving the Church as a mystery of the Kingdom of God, present in history through the sanctifying work of the Church, keeps us from a misunderstanding of the missionary theology. Through the work of salvation which the embodied

41 I. Bria, Credinţa pe care o mărturisim, Bucureşti, Ed. IBMBOR 1987, p. 92, 94.

42 Idem, Curs de teologie, p. 4. 
Son did, the whole creation was redeemed and the gates of the Kingdom of God were opened for everybody, even though many are not aware of it. The whole creation is called to become a Church. According to Saint Maxim the Confessor, "the Holy Church of God is the icon of the whole universe”. ${ }^{43}$ This is why the Christian mission can be done only in, through and for the Church, which is the place where the sanctification of the universe happens. The Orthodox mission has a specific ethos which is very much related to the understanding of the Church in the Orthodox theology. The Church is not just a missionary institution, but a sacred event or a mystery of God which must be experienced, and only after that defined. It is a divine-human reality with an institutional character. The Church is described using biblical metaphors such as "the body of Christ” or "the bride of Christ”, which means that the work of Christ in the world is present in the Church, and the Church continues the mission of Christ. The Church is presented using the antonymic model that characterizes the whole of reality. In this case, the Church is the sacrament of the Kingdom of God, which can be anticipated in the Church, especially in the Holy Liturgy, and will be fully inaugurated in the parousia (second coming) of God. It has a very important eschatological dimension. The missionary character of the Church is a consequence of its apostolicity.

Therefore, in the Eastern Orthodox understanding, the mission refers to the fulfilling of the will of God on earth, as a sign of an anticipated presence of the Kingdom of God in the world. The mission will always move from within the Christian life towards outside. This means that it requires a personal spiritual transformation and that a Christian is, above all, a witness for the world. It is a mission to attract the others rather than convert, following the example of the first Christian community from Jerusalem. „The mission of the Church is not created by Christians. God calls the Church to surrender to Christ as his holy body, and has chosen his sons and daughters to work for the sake of the salvation of all". ${ }^{44}$

\section{Missio Dei formula in the Orthodox Contemporary Missiology}

Recent researches have shown that the notion of missio Dei needs to be studied further, insisting upon the pneumatological, Christological and Trinitarian bases of the mission, since the revelation of God as Trinity underlines the fact that God is in Himself a life of communion and that through

43 St. Maxim Mărturisitorul, Mistagogia 2, translated by D. Stăniloae, Bucureşti, Ed. IBMBOR 2000, p. 15.

44 I. Bria, „Orthodoxy and Mission”, in: International Review of Mission, vol. 89, nr. 352, (1/2000), p. 50. 
His work He attracts the humanity and the whole creation to this communion of true life with $\mathrm{Him}^{45}$.

The Christian mission has its basis and its starting point in the eternal communion of the Holy Trinity, in the movement of God's love toward the Son in the Holy Spirit, and through Him toward the whole world. Therefore, the mission is a contribution to the sending of the Son (John 20, 21-23) and of the Holy Spirit (John $14,26)$ into the world. They reveal God's life of communion in order to make us acolytes to it. Therefore, the mission of the Church is based on the deliberated sending of the Son and of the Holy Spirit into the world by the Father and on the explicit command which the resurrected Lord gave to the Apostles: that of preaching the Gospel, of calling to repentance and of baptizing in the name of the Holy Trinity (Matthew 28, 18-29) ${ }^{46}$.

One of the Orthodox theologians who were actively involved in the ecumenical movement was Professor Ion Bria. He made significant contributions to the development of the contemporary mission theology. $\mathrm{He}$ underlined the martyria dimension of mission instead of an offensive and sometimes arrogant mission, the liturgical aspect of Christian witness in the form of the Liturgy after the liturgy, but also the Trinitarian importance of the missio Dei theology. ${ }^{47}$

The centre and content of the mission of the Church is to proclaim the salvation of humankind as a gift of God, given in the cross and the resurrection of his Son, Jesus Christ. Mission is an essential part of the gospel of Jesus Christ. His commandment in Matthew 28: 18-20 or Mark 16: 15 is the basis of the apostolic vocation of the church. This commandment, a concrete historical conclusion of the gospel fulfilled in the power of the Holy Spirit since Pentecost, is built on the perception of God the Father, who sent his Son in whom and through whom he speaks and communicates, is present in our midst. Mission is rooted in the very being of God who reconciles, restores, and heals humanity and creation in the sufferings and pain of Jesus Christ. The church's mission is missio Dei, 'mission in Christ's way'. The

\footnotetext{
45 Valer Bel, „Missio Dei”, in: Ioan Chirilă (ed.), Misiunea Bisericii în Sfânta Scriptură şi în istorie, Cluj-Napoca, Ed. Renaşterea 2006, p. 10-11.

46 V. Bel, Misiunea Biserici în lumea contemporană. 1 Premise Teologice, Cluj-Napoca, Presa Universitară Clujeană, 2004, p. 15-16; I. Bria, Curs de teologie, p. 3.

47 Petros Vassiliadis, „An Orthodox assessment of the new mission statement”, in: International Review of Mission, vol. 102, nr. 397, (11/2013), p. 175.
} 
vision, the hope of mission, is one: God's purpose to reconcile all humanity into unity in Christ. The rediscovery of the theological foundation of mission requires an understanding of how our missiology is related to our ecclesiology, and vice-versa. Missio Dei is not a matter of rhetoric. It means that the confession of the truth revealed in Jesus Christ, the revelation of the risen Christ is fundamental for the church's identity. The Holy Spirit constitutes the historical church together with Jesus Christ, and the church has to live and witness her identity with Him 'until He comes' again, through the word and sacraments. Those who received the Episcopal ministry (episcope) have the responsibility of sending missionaries to establish new Christian communities. Catholic, Orthodox and Protestants agree on that principle. The missionary departments are integrated into ecclesiastical structure. Missio Dei means also to carefully check the images of God, those key theological phrases one uses in mission, precisely to avoid any amalgam with nebulous syncretism. From the beginning the churches have protected the apostolic faith - that paradosis which preserves the gospel of Jesus Christ. ${ }^{48}$

\subsection{Missio Dei as liturgy after Liturgy}

Ion Bria uses missio Dei to rediscover the theological foundation of mission. According to him, missio Dei reveals how ecclesiology is related to missiology and vice-versa. "Missio Dei is not a matter of rhetoric. It means that the confession of the truth revealed in Jesus Christ, the revelation of the risen Christ is fundamental for the church's identity. The Holy Spirit constitutes the historical church together with Jesus Christ, and the church has to live and witness its identity with Him 'until He comes' again, through the word and sacraments." ${ }^{49}$

Then, in I. Bria's missiology we can find a Trinitarian missiology, with the participation of the entire community in God's work (missio Dei) of salvation and sanctification of the world. And this role can be observed in the Liturgy. „... it is necessary to rediscover in the Liturgy that lex orandi from the Church's beginning in its cosmic, redemptive and eschatological dimensions. [...] The Liturgy builds and replenishes the Church through its virtue of Kingdom sacrament; it makes from us, the Church's believers, Christ's witnesses." ${ }^{50}$ I. Bria considers that in Liturgy the Church genuinely

48 I. Bria, „Orthodoxy and Mission”, p. 53.

49 Ibidem.

50 I. Bria, Liturghia după Liturghie, București, Ed. Athena 1996, p. 30. 
keeps the face of the apostolic community ${ }^{51}$. Here, the believers can experience the coming Kingdom, because the Eucharist always has an eschatological perspective. ${ }^{52}$ The Christian who takes part in the Sacred Liturgy is a witness. Before receiving the Body and Blood of Christ he says the following words: „I believe, Lord, and I witness...”. Through the Eucharist, he experiences the coming Kingdom and says: „We have seen the true Light, we have received the heavenly Spirit, we have found the true faith: we adore the indivisible Trinity...". However, the orthodox liturgical spirituality does not limit itself to the place of worship and to receiving the Holy sacrament. We receive Christ's Body for the world's life. With that „Let us go forth in peace... In the name of the Lord", the Christian is sent out into the world to practice another form of "liturgy”, not the Eucharistic one, but its follow-on ${ }^{53}$, „the peer's liturgy”. Christ is in the middle of us all, men and women, who found themselves in adverse conditions. He gives them credence, therefore, he who is merciful to the poor, is merciful to God. The Christians practice towards them a ministry of love and mercy, a liturgy of the peer where they can find Christ." ${ }^{44}$

In the same perspective, Fr. John Njoroge highlights that in the Orthodox sense, worship is not only the expression of "Christ's saving ministry, death, resurrection and ascension". It is also the expression of the Christians' communion to the living hope in the coming kingdom of God. As a community, they are empowered to take part entirely in God's work (missio Dei) of salvation of the world. Therefore, at the end of the Sacred Liturgy, the priest utters the following words: "let us go forth in peace". According to Fr. Ion Bria, these words mean that every believer and the whole community, in fact, is being sent to a mission into the world and to witness that the kingdom is coming. From this point, Christians who have heard the word and received the Body and Blood of Christ should be "living prophetic signs of the kingdom". These words also suggest that liturgy spiritually prepares its participants for mission. This is reflected by the ethos of the entire Orthodox theology around "the gathering of a wor-

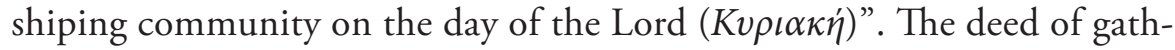
ering, as well as the idea of the Eucharist are set within the framework of a communion, "not only the communion between the living and the dead but also with the saints and the heavenly bodiless powers". This commun-

51 Idem, Destinul Ortodoxiei, București, Ed. IBMBOR 1989, p. 314.

52 Ibidem, p. 317.

53 Ibidem, p. 319.

54 Idem, Liturghia după Liturghie, p. 108. 
ion mirrors the Trinitarian communion making the Eucharistic liturgy the starting point for mission. ${ }^{55}$

\subsection{Missio Dei as a relational and synergetic theology}

In Petros Vassiliadis' opinion, the church is a leading means in the missio Dei, among many other powers of the world used by God for the salvation of mankind and the entire creation. Thus, according to him, "the emphasis in mission is no longer placed on mere proselytic activities, but on full-scale conversion of both the Christian evangelizers and those to whom the witness is rendered". Hence, the carrying out of God's rule more easily becomes a reality, since according to the biblical Magna Carta (Matthew 25), God uses other than the conventional religious criteria to judge humanity. The "economy of the Spirit" allows for the narrow boundaries of the Church to be widened, enabling a "common witness" and a humble "inter-faith dialogue".

The Orthodox generally understand the Church in terms of getting together, with mission coming only as a result of it, as a "Liturgy after the liturgy", and the believers going forth in peace (in mission) only after having experienced the eschatological Kingdom of God in the Eucharistic liturgical service. In the West it was generally the other way round: Mission was a fundamental element of their identity and in some cases prior to the Eucharist. The early Church, her understanding of herself (ecclesiology) and her theology of mission (missiology) developed on the eschatological teaching of Jesus about the Kingdom of God. As regards ecclesiology in the Orthodox Church, even the episcopocentric structure of the Church reflects the eschatological vision of the Church. In the Eucharistic community, the bishop is understood as an image of Christ. That also explains why the entire Orthodox theology and life are centred on the resurrection: "the Church exists not because Christ died on the Cross, but because $\mathrm{He}$ is risen from the dead, thus becoming the aparche (beginning) of all humanity". As regards missiology, the apostles - and all Christians thenceforth - were assigned to proclaim not a set of given religious beliefs, doctrines, and moral rules, but the coming Kingdom, "the good news of a new reality to be established in the last days". In the centre of this Kingdom we find not the powerful emperor, but "the humble, crucified and resurrected Christ", Whose continuous presence we feel "through the Holy Spirit in a life of communion, in a life of full-scale reconciliation". ${ }^{56}$

\footnotetext{
55 John Njoroge, „Common Mission as a Task for Orthodox Involvement in Ecumenism”, in: Pantelis Kalaitzidis et al. (eds.), Orthodox Handbook on Ecumenism. Resources for Theological Education, Geneve - Oxford - Volos, Volos Academy Publications, in cooperation with WCC Publications and Regnum Books International, 2014, p. 648.

56 P. Vassiliadis, „Theological Foundations of Mission: An Orthodox Perspective”, in: P. Vassiliadis (ed.), Orthodox Perspectives on Mission, Regnum Edinburg Centenary Series, 17, Oxford, Regnum Books International 2013, p. 192.
} 
In the Orthodox tradition, human nature was never a closed, independent and immovable entity; its very existence was always determined by its relationship to God. Led, hence, by a vision of how to "know" God, the Orthodox considered their witness in close bond with the notion of a synergetic soteriology and the anthropology of theosis or deification. This relational and synergetic theology has developed in a much more inclusive understanding of mission than the conventional exclusivist one inherent to the pre-ecumenical era in almost all missionary ventures in the West. Of course, we should be careful not to alienate the "economy of the Spirit" from the "economy of Christ/the Word"; the Pneumatology should never dim Christology. The Orthodox vision of mission has never urged a universal proselytism, but the genuine witness of the Church's eschatological experience. Actually, this was made possible by defining missio Dei based on John 21 and the fundamental assumption of Trinitarian theology, "that God in God's own self is a life of communion and that God's involvement in history aims at drawing humanity and creation in general into this communion with God's very life." 57

\subsection{Love - the motive of the missio Dei}

According to Anastasios (Yannoulatos), missionary God loves His creation, and this love is the motivation for mission. A. Yannoulatos didn't use expressis verbis the missio Dei but he developed a Trinitarian Theology of mission. For a better understanding of what A. Yannoulatos stated in this context, it would be useful for us to remember that, in general, the theological thinking of the Eastern Church moves within a larger theological and cosmological frame, in which the dominant element is Saint John's conception on the love of the Trinitarian God, seen in the contemplation of God's mystery in an eschatological and doxological perspective ${ }^{58}$.

According to the Archbishop A. Yannoulatos, "God's glory, seen in the perspective of His endless love, is the fundamental key for the understanding of the whole course of history. According to the Orthodox understanding, God remains "the Alpha and the Omega" (Rev 21, 6), "the First and the Last" (Rev 1, 17). He is "who is, who was, and who is to come" (Rev $1,8)$, the One worthy to receive the praise, glory and power, for He Himself created everything and through His will it all came to existence". "The evolution of the history of humankind, of which the Holy Scripture speaks, starts with God's glory and ends with God's glory. When Christ says: "And now

57 Ibidem, p. 193.

58 Anastasios Yannoulatos, Mission in Christ's Way: An Orthodox Understanding of Mission, Brookline - Geneva, Holy Cross Orthodox Press 2010, p. 41-42 
Father, glorify me in your presence with the glory I had with you before the world began" (John 17:5), He proves the fact that "God's glory" was a condition which existed before the Creation. Regarding the end of the history, it is characteristic the fact that the last book of the Holy Scripture speaks a lot about the glory that God receives and describes the heavenly Liturgy, to which those saved in Christ "from every tribe and language and people and nation" $(\operatorname{Rev} 5,9)$ take part ${ }^{59}$.

In other words, the Trinitary-God, God, Who is love, brings the world into existence for it to enjoy God's glory. The relationship between the Creator and Creation is from the very beginning marked by humble love. The world and man are not brought to existence by accident or by a philosophical necessity, but by God's free will, motivated by this love which leaves room to the other too. Why do we call it humble love instead of just love? According to Saint Isaac the Syrian, God is in Himself the absolute plenitude (fullness) and abyss of humbleness.

The natural praise of the humankind towards God's glory was altered by Adam's sin, which misconstrues humankind towards separation and egocentrism, underestimation and ignorance for God's glory. The revelation of the divine glory within the kenosis and within the infinite humble love of God and the call for unity, are linked together within the mystery of redemption. They are a single movement whose promoter is God - a movement that produces a radical change in the process of the history of humankind ${ }^{60}$. The movement we are talking about is the sending of the Son for the life and salvation of the world. The most complete manifestation of God's love for His creation is the embodiment of His Beloved Son: "For God so loved the world that he gave his one and only Son, that whoever believes in him shall not perish but have eternal life. For God, did not send his Son into the world to condemn the world, but to save the world through him" (John 3:16-17). Christ, out of love for man, redeemed us from sin and opened to us the gates of the communion with God. And also out of love for man, God sent us the Holy Spirit in order to transform into love the selfishness within, through the mysterious death and resurrection together with Christ and thus we could live within the relationship of communion with God and our neighbors. From this moment on, we may speak about the role of love within the missionary work of God (missio $D e i)$ or we may speak about love as the motive of the mission, understood in this context as a work of redemption.

59 Ibidem, p. 42.

60 A. Yannoulatos, Mission in Christ's Way, p. 42. 


\subsection{Cabasilean missio Dei}

Athanasios N. Papathanasiou offers another interpretation of the missio Dei, telling us a story from the time of Nicholas Cabasilas. Cabasilas speaks about the exciting idea of missio Dei, which has fervently been discussed by ecumenical Christians since 1952, emphasizing the fact that Christ has been working where the Church is not. God is the missionary par excellence, who endlessly works for the salvation of His creation, and the Church is a deacon of His mission, a witness of His love for the whole world and a foresight of the Kingdom to where he is calling the universe. So, N. Cabasilas' missio Dei carries two specific characteristics: 1 . The agent is the incarnate Christ. N. Cabasilas emphasizes that "what has radically changed human fate has been the divine incarnation and death" ${ }^{61}$. 2. N. Cabasilas explicitly states that "there are saints who accepted truth neither by means of listening to the Church's preaching nor by observing miracles, but through a mystical baptism that Christ himself had the initiative to perform for them". N. Cabasilas calls attention to the example of three martyrs in the early centuries: Porphyrius, Gelasius and Ardalion, all mime actors who used to mock Christians. Cabasilas reports that Porphyrius had the chance to hear many things about Christ and see miracles, but remained immovable in his denial. One day he was mimicking Christian baptism and pretending to baptize himself. Yet the Grace of God touched him and when he came out of the water he confessed Christ and eventually was martyred. The same happened with Gelasius. The story of Ardalion is different. He was playing the role of a Christian martyr in torture, so his fellow-actors hanged him naked upon a cross. Then, suddenly, he accepted Christ, declared his faith and became a martyr. ${ }^{62}$

In all three cases, Cabasilas speaks about eros, the fiery love that Christ Himself generated "descending upon" the actors' hearts. Especially for Ardalion he notes: "As soon as the actor uttered his lines, that he loved Christ, he at once began to love Christ [...]. For other men, the good proceeds to the mouth 'from the good treasure of the heart' (Mathew 12, 35), but for Adralion the treasure of goods above flowed from his heart to his mouth. Christ

\footnotetext{
${ }^{61}$ Athanasios N. Papathanasiou, "A Theological Affirmation of God's Action Outside the Canonical Boundaries of the Church", in: P. Kalaitzidis et al. (ed.), Orthodox Handbook on Ecumenism. Resources for Theological Education, Geneve - Oxford - Volos, Volos Academy Publications in cooperation with WCC Publications and Regnum Books International 2014, p. 90; A. N. Papathanasiou, „If I Cross the Boundaries, You Are There! An Affirmation of God's Action Outside the Canonical Boundaries of the Church", in: Communio Viatorum, No. 3, (LIII), 2011, p. 50.
}

${ }^{62}$ A. N. Papathanasiou, 'A Theological Affirmation of God's Action Outside the Canonical Boundaries of the Church', p. 90. 
laid hold on him [Ardalion] and attached him, so that He persuaded him of the things which he formerly could not bear even to hear". ${ }^{63}$

\subsection{Missio Dei, missio Israelis}

A young Romanian theologian, Cosmin Lăuran, wrote his $\mathrm{PhD}$ thesis on mission, around the idea of missio Dei. According to C. Lăuran, stating that God is missionary par excellence enables us to talk about mission even before the sending of the Son to the world (hence missio Israelis). The discussions included propositions and theological developments of the kind of the pair missio Dei generalis ${ }^{64}-$ missio Dei specialis ${ }^{65}$, where the first collocation makes reference to the direct action of God throughout history, at a personal level (particular conversions) or at a communitary level, or even through the nature's impersonal forces or through historical events, while the second one regards God's mission in the world through His missionaries. In this sense, God is a Deus mittens ${ }^{66}$, a God Who sends, which implies the missionary nature of man: if God is the One Who sends, then man is a homo missum $^{67}$, a missionary being. Furthermore, if God is a missionary God, then the man, created „in His own image, in the image of God”, bears the same missionary nature ${ }^{68}$ On the other hand, like the Holy Scriptures teach us, the man has Christ's „image”, but as Christ is the Sent par excellence, the man has the duty to take part in this mission, by virtue of his nature. ${ }^{69}$

\section{Conclusion}

As far as the Eastern Orthodox theology is concerned, the faith in the Holy Trinity separates the Christian doctrine about God from other doctrines, in the sense that only this type of divinity can offer salvation and can constitute the basis of a communion of life and love with us in eternity. From this point of view, the mission of the Church is based on missio Dei, the movement of the Father's love toward the Son, in the Holy Spirit and,

\section{Ibidem.}

${ }^{64}$ Cf. J. G. Flett, The Witness of God: The Trinity, Missio Dei, Karl Barth, and the Nature of Christian Community, Grand Rapids, Wm. B. Eerdmans Publishing 2010, p. 41.

65 Georg Friedrich Vicedom, The Mission of God, An Introduction to a Theology of Mission, St. Louis, Concordia Publishing House 1965, p. 15, p. 51-60.

66 Cosmin Lăuran, Missio Israelis O lectură misionară a Vechiului Testament cu referire specială la cărțile Pentateuhului, Teză de doctorat, Universitatea „Babeș-Bolyai”, Cluj-Napoca, 2015, p. 48.

67 Ibidem, p. 69-125.

68 Ibidem, p. 53, 68.

69 Ibidem, p. 53, 68. 
through Him, toward the whole world. This is why the main purpose of the Church mission is not the propagation of some intellectual convictions or of moral commandments, but the conveyance of the life of communion in God or, in other words, attracting people to the communion with the Holy Trinity. „It can be said that this is a plan of the Holy Trinity designed for the whole creation, whose purpose is to be the Kingdom of God"70.

Thence, the Orthodox Missiology understands the work of God in the world as a mission of God for the entire creation. The mission is not an instrument in the hand of some so called missionary societies which impose not only the gospel, but also their culture and way of living as the only one possible. The missio Dei paradigm required the indigenization of the Gospel in specific contexts and the growing of the Christian life in harmony with the culture of the specific context. The proof that the mission is a missio Dei is the fact that in the Global South the Church grows rapidly and in a different manner than in the Global North. This fact is obvious not only in the Protestant communities but also in the Roman-Catholic and the Orthodox communities that are more conservative as far as Liturgy or Spirituality is concerned.

The Orthodox understanding of missio Dei emphasizes the notion of theosis (deification). Through the Sacraments and the life of the Church, Christians experience the very life of God, by the Spirit of Christ. This is mainly expressed in the Church as a community of members of the Christ's body, extended in the world. In this case, the Christian identity becomes an issue of missionary identity. Having the experience of God especially in the Liturgy and in the ascetical life, the Christian communities don't have the option to keep the good news only to themselves. They have to testify this life experience to the entire world as a liturgy after Liturgy and as a witnessing of the reconciliation and sanctification of the entire creation. Therefore, missio Dei is also the fulfilling of the will of God on earth, as a sign of an anticipated presence of the Kingdom of God in the world. The mission will always move from within the Christian life towards outside. This means that it requires a personal spiritual transformation and that a Christian is, above all, a witness for the world. It is a mission to attract the others rather than convert, following the example of the first Christian community from Jerusalem. The continuous work of God in the internal life of the church requires a continuous response from the Christian. Therefore, the never-ending call of God to deification is a missio Dei which expects an answer from all the believers. Even so, if the answer is given, the continuous growing of the Christian "unto a perfect man, unto the measure of the stature of the fullness of Christ" (Ephesians 4, 13) is also a way of participating in the missio Dei.

70 G. Petraru, Misiologie ortodoxă, p. 170. 
Along with the acknowledged interpretation of missio Dei, the Eastern Orthodox theology seems to register a kind of fresh approach to mission, in which the work of God as a work of the Holy Trinity is perceived as an action outside the "canonical” Church centered missiology. „Cabasilian” missio Dei and missio Israelis could be landmarks in this perspective. This is another proof of the theological richness of the missio Dei formula, and of the thriving contemporary orthodox theology of mission. 